\title{
Recent developments in transcriptional and translational regulation underlying long-term synaptic plasticity and memory
}

\author{
Ashok N. Hegde and Spencer G. Smith \\ Department of Biological and Environmental Sciences, Georgia College and State University, Milledgeville, Georgia 31061, USA
}

\begin{abstract}
Formation of long-term synaptic plasticity that underlies long-term memory requires new protein synthesis. Years of research has elucidated some of the transcriptional and translational mechanisms that contribute to the production of new proteins. Early research on transcription focused on the transcription factor cAMP-responsive element binding protein. Since then, other transcription factors, such as the Nuclear Receptor 4 family of proteins that play a role in memory formation and maintenance have been identified. In addition, several studies have revealed details of epigenetic mechanisms consisting of new types of chemical alterations of DNA such as hydroxymethylation, and various histone modifications in long-term synaptic plasticity and memory. Our understanding of translational control critical for memory formation began with the identification of molecules that impinge on the $5^{\prime}$ and $3^{\prime}$ untranslated regions of mRNAs and continued with the appreciation for local translation near synaptic sites. Lately, a role for noncoding RNAs such as microRNAs in regulating translation factors and other molecules critical for memory has been found. This review describes the past research in brief and mainly focuses on the recent work on molecular mechanisms of transcriptional and translational regulation that form the underpinnings of long-term synaptic plasticity and memory.
\end{abstract}

Biochemical studies linking memory formation and consolidation began more than half a century ago (Flexner et al. 1965). The advent of molecular biology provided neuroscientists with many tools necessary to probe the molecular underpinnings of memory. As a result, substantial data have been accumulated on how protein synthesis plays a role in memory. This progress has paralleled advances in the knowledge of transcription and translation in nonneuronal systems. Beginning with the discovery of role of cAMPresponsive element binding protein (CREB), numerous studies have elucidated the role of transcription in memory formation (Yin and Tully 1996; Kandel 2012; Smolen et al. 2019). Similarly work on translation focused mainly on the molecules that regulate protein synthesis by interacting with the $5^{\prime}$ and $3^{\prime}$ untranslated regions (UTR) of mRNAs (Darnell and Richter 2012; Hinnebusch et al. 2016; Sossin and Costa-Mattioli 2018).

Reviewing a subject of this vast scope is a daunting task. Because many excellent reviews have been written on both transcriptional and translational mechanisms underlying memory, in this article we focus on relatively recent developments (research published mainly in the past two decades) in both of these fields and give a bird's eye view.

\section{Early research on transcription underlying long-term synaptic plasticity and memory: role of CREB}

Evidence for the role of CREB in long-term synaptic plasticity came from investigations on long-term facilitation (LTF) in Aplysia. In this invertebrate animal, serotonin (5-HT) is the neurotransmitter that functions to strengthen the synapses. The 5-HT receptors in Aplysia produce the second messenger cAMP via a G-proteincoupled pathway. Previous work had also established a requirement for macromolecular synthesis for development of LTF

\section{Corresponding author: ashok.hegde@gcsu.edu}

Article is online at http://www.learnmem.org/cgi/doi/10.1101/lm.048769.118.
(Montarolo et al. 1986). Therefore, it was logical for researchers to look for a possible role of CREB in gene expression in sensory neurons of Aplysia, which is where the molecular changes important for the presynaptic LTF occur. When the oligonucleotides with cAMP-responsive element were injected into sensory neurons, LTF was significantly blocked (Dash et al. 1990). Subsequently, evidence for the role of CREB in long-term memory was obtained in the Drosophila model (Yin et al. 1994) using expression of a dominant-negative CREB. In the same year, evidence was also published showing that a mutation in the CREB gene causes deficiency in memory in mice (Bourtchuladze et al. 1994).

\section{After CREB: other transcription factors that play a role in long-term synaptic plasticity and memory}

Following the studies on CREB, several transcription factors have been shown to play a role in long-term synaptic plasticity and memory. Some of them are described below (See Table 1; Fig. 1).

\section{$\mathrm{Nr} 4$ (nuclear receptor 4)}

This belongs to a family of three transcription factors (Nr4a1, $\mathrm{Nr} 4 \mathrm{a} 2$, and Nr4a3) encoded by immediate-response genes. Nr4a1 is also known by the names Nurr77/NGIB/TR3. Nr4a protein was originally described as an orphan nuclear receptor because of the lack of a known ligand. Expression of $\mathrm{Nr} 4 \mathrm{a}$ increases in response to inhibitors of histone deacetylases (Hawk et al. 2012). Nr4a

2019 Hegde and Smith This article is distributed exclusively by Cold Spring Harbor Laboratory Press for the first 12 months after the full-issue publication date (see http://learnmem.cshlp.org/site/misc/terms.xhtml). After 12 months, it is available under a Creative Commons License (AttributionNonCommercial 4.0 International), as described at http://creativecommons. org/licenses/by-nc/4.0/. 
Table 1. Function of transcription factors in memory

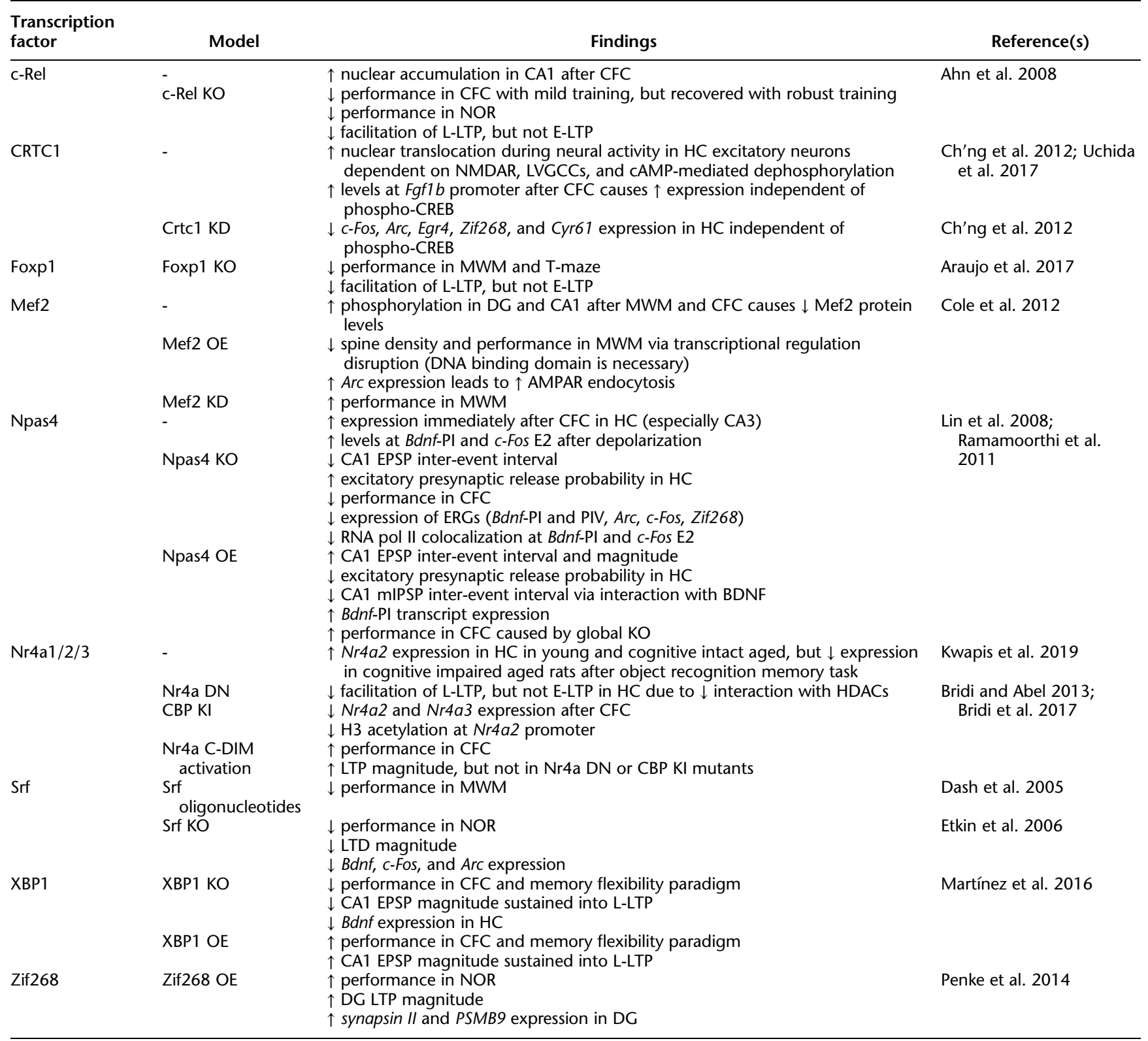

CA1, cornu ammonis 1; CA3, cornu ammonis 3; CFC, contextual fear conditioning; DG, dentate gyrus; DN, dominant negative; E-LTP, early-phase LTP; EC, entorhinal cortex; ERG, early response genes; HC, hippocampus; KI, knockin; KO, knockout; L-LTP, late-phase LTP; LVGCC, L-type voltage-gated calcium channels; $\mathrm{MWM}$, Morris water maze; NOR, novel object recognition task; OE, overexpression.

expression depends on signaling by the cAMP-dependent protein kinase and activity of CREB suggesting that Nr4a might be important for a second wave of transcription underlying long-term synaptic plasticity and memory. In hippocampal slices from mice expressing a dominant-negative $\mathrm{Nr} 4 \mathrm{a}$ transgene, transcriptiondependent late-phase long-term potentiation (L-LTP) is impaired (Bridi and Abel 2013). Synthetic ligands of $\mathrm{Nr} 4 \mathrm{a}$, para-phenyl substituted di-indolyl methane analogs or C-DIM compounds increase the duration of LTP and enhance contextual fear memory (Bridi et al. 2017). With respect to other Nr4a isoforms, knockdown experiments showed that Nr4a1 is necessary for memory for object location whereas $\mathrm{Nr} 4 \mathrm{a} 2$ is necessary for long-term memory of both object location and object recognition (Table 1; Fig. 1; McNulty et al. 2012). It appears that the Nr4a isoform Nr4a2 is crit- ical for preserving cognitive abilities in old age because it has been shown that histone deacetylase 3 (HDAC3)-mediated repression of $\mathrm{Nr} 4 \mathrm{a} 2$ contributes to cognitive decline. Other $\mathrm{Nr} 4 \mathrm{a}$ isoforms seem to contribute to the prevention of cognitive decline as well. Overexpression of Nr4a1 and Nr4a2 transcripts individually or together in the dorsal hippocampus of male mice can mitigate age-related impairment in object location memory (Kwapis et al. 2019).

\section{Npas4 (neuronal PAS domain protein 4)}

The PAS domain in Npas4 (and other proteins) is named after the structural motifs found in the proteins Period, Aryl hydrocarbon receptor and Single-minded which assist in protein-protein 


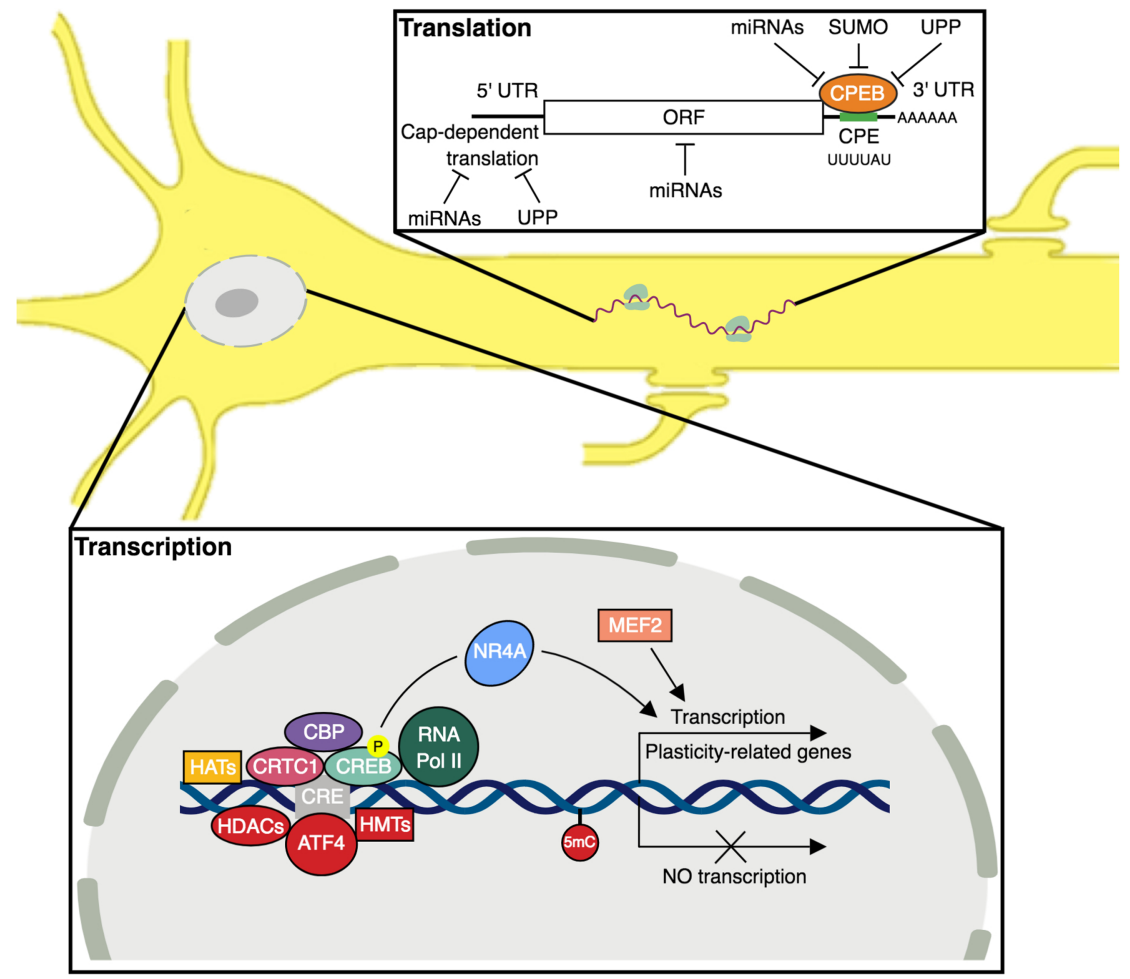

Figure 1. Molecules of transcription and translation underlying long-term synaptic plasticity and memory. Schematic figure showing a neuron with representative molecules that regulate transcription (below the neuron) and translation (above the neuron) during long-term synaptic plasticity and memory. for early-phase and late-phase LTP. This study suggested that the transcriptional program activated by Srf might run parallel to that of CREB (Ramanan et al. 2005). Later studies showed that Srf is also important for LTD and the formation of immediate memory in mice to a novel context (Etkin et al. 2006). A separate investigation showed that infusions of oligonucleotides containing binding sites for Srf into the rat hippocampus impaired spatial memory (Dash et al. 2005).

\section{Mef2 (myocyte enhancer factor 2)}

This is a transcription factor that restricts dendritic spine growth. Increasing Mef2 in the dentate gyrus and amygdala of mice impairs spatial and fear memory formation respectively. Conversely, decreasing the levels of Mef2 in the same brain regions enhances spatial and fear memory. Interfering with AMPA receptor (AMPAR) endocytosis rescues the adverse effect of Mef2 on memory formation. It is thought that Mef2 indirectly causes a decrease in surface expression of AMPARs through one of its target genes Arc (Cole et al. 2012). Based on the investigations conducted thus far, it appears that Mef2 does not have a connection to the CREB pathway of gene expression. interactions. Npas4 is the protein product of an immediate-early gene whose transcriptional activity is required for inducing genes in the CA3 region of the hippocampus that play a role in contextual memory formation. Global knockout of Npas4 impairs contextual fear conditioning (CFC). In addition, selective deletion of Npas4 in CA3 but not CA1 of the hippocampus hinders CFC (Ramamoorthi et al. 2011). Npas4 was initially identified as a transcription factor required for inducing expression of activity-dependent genes during the development of inhibitory synapses (Lin et al. 2008). Therefore, the transcriptional program mediated by Npas 4 might be important for tweaking the feedforward inhibition in the hippocampus in order to make the context of memory precise.

\section{Foxpl (forkhead box PI)}

This is a transcription factor that belongs to the forkhead family of DNA-binding proteins previously known to be important for development of the brain and other organs. There has been a resurgence of interest in Foxp1 because heterozygous mutations and deletions in the human FOXP1 gene are linked to autism spectrum disorder and intellectual disability. Experiments using mice with conditional knockout of Foxp1 in pyramidal neurons of the neocortex and CA1 and CA2 subregions of the hippocampus show impairment in spatial memory but not generalized deficits in learning and memory. Moreover, in the hippocampal slices prepared from Foxp1 knockout mice maintenance of CA1 LTP is impaired (Araujo et al. 2017).

\section{Srf (serum response factor)}

Initial work on Srf showed that it is critical for expression of immediate-early genes such as c-Fos and Egr1 (a.k.a. Zif268) and

\section{CRTCl (CREB-regulated transcriptional coactivator 1)}

This protein binds to the bZIP domain of CREB and works with it to regulate transcription. CRTC1 has been shown to reside in silent synapses and translocate to the nucleus in an activity-dependent manner. Its persistence in the nucleus requires cAMP signaling (Ch'ng et al. 2012). Subsequent studies showed that CRTC1 regulates the transcription of $F g f 1$, a gene that encodes fibroblast growth factor. With weak synaptic stimulation CRTC1 complexes with CREB-binding protein (CBP), however, it makes a complex with KAT5 upon strong stimulation. KAT5 is also a histone acetyltransferase like CBP. Its recruitment to the promoter of the Fgf1 gene appears to be specifically associated with an increase in H4K12 acetylation (Uchida et al. 2017). It is tempting to speculate that flexibility of CRTC1 in associating with more than one factor might be indicative of combinatorial regulation of transcription factor assemblies which greatly increases their power in controlling the specificity of gene expression.

Other transcription factors such as c-Rel, XBP1and Zif268 also have a role in long-term synaptic plasticity and memory and are briefly described in Table 1 (Ahn et al. 2008; Penke et al. 2014; Martínez et al. 2016).

\section{Transcriptional repressors: role in long-term synaptic plasticity and memory}

Repressors of transcription can reduce the expression of synaptic plasticity-related genes and thus have a negative impact on memory formation. A corollary is that the removal of transcriptional repression should enhance memory. This is precisely what was found in mice expressing an Atf4 transgene which showed an improvement in spatial memory (Chen et al. 2003). Atf4 (also called 
Creb2) is a CREB repressor and down-regulates transcription when bound to CREs. In Aplysia, two CREB repressors have been shown to play a role in long-term synaptic plasticity, namely Creb1b and Creb2 (Bartsch et al. 1995, 1998). In order for CREB-mediated gene expression to go forward, repression has to be removed. This is likely to be accomplished by targeted degradation by the ubiquitin-proteasome pathway (UPP). Atf4 protein is degraded during long-lasting LTP in the mammalian hippocampus (Dong et al. 2008). CREB1b is subject to degradation by the UPP upon stimulation of sensory neurons by repeated application of the neurotransmitter 5-HT which induces long-term facilitation in Aplysia (Upadhya et al. 2004).

Another transcriptional repressor known to repress CREBmediated transcription is called DREAM (downstream regulatory element antagonist modulator). DREAM binds to the leucine-rich domains located within the kinase-inducible domain of CREB and interferes with recruitment of CBP by phosphorylated CREB. The Dream (-/-) mutant mice show enhanced object recognition memory (Fontán-Lozano et al. 2009) and knocking out of KChIP3, which has $99 \%$ homology with Dream, improves contextual fear memory (Alexander et al. 2009).

In addition, transcriptional corepressors are known to exist. These tend to be large complexes of proteins often incorporating histone-modifying enzymes such as HDACs (Schoch and Abel 2014). Much of the evidence on these corepressors came from cancer research. It is interesting to note that a transcription factor with a role in memory Mef2 (described above) forms a corepressor complex with HDAC and SIN3A and blocks the expression of Nurr77 (Nr4a) another transcription factor that functions in memory formation. In Jurkat $\mathrm{T}$ cells, in response to $\mathrm{Ca}^{2+}$ signal, the repression is relieved and Mef2 associates with CBP to activate transcription of Nurr77 (Youn and Liu 2000). Therefore, it is likely that the activity-dependent regulation of transcriptional corepressors plays a role in controlling transcription underlying long-term synaptic plasticity and memory although the molecular details are likely to be different from those observed in nonneuronal cells.

\section{Epigenetic control of transcription: DNA methylation and histone modification}

\section{DNA methylation}

Methylation of cytosine residues at the fifth position (5-methyl cytosine) as an epigenetic modification was previously known to silence gene expression in the context of development of organisms and differentiation of tissues. DNA methylation came under the radar of scientists researching synaptic plasticity and memory only about a decade or so ago (Miller and Sweatt 2007). The 5 -methyl cytosine modification of DNA occurs by the action of DNA methyltransferases of which several isoforms exist. The reaction can be reversed by DNA demethylases. A protein named Gadd45b (growth arrest DNA damage-inducible $\beta$ ) which promotes demethylation has been shown play a role memory formation. Gadd $45 b$ knockout mice showed impaired fear conditioning (Leach et al. 2012). These results make sense and conform to the previous notion that DNA methylation decreases gene expression and DNA demethylation promotes it. However, the situation may be more complex and depend on the pattern of DNA methylation (or demethylation) and may be modified by neuronal activity. Taken in that light, the memory-promoting activity of a DNA methyltransferase makes sense. For example, restoring age-related decline in a DNA methyltransferase Dnmt3a2 by adeno-associated virus-mediated expression improved fear memory as tested by contextual and trace fear conditioning paradigms (Oliveira et al. 2012).
Over the last few years, proteins that convert 5-methyl cytosine to 5-hydroxymethyl cytosine (5-hmc) have been discovered (Tahiliani et al. 2009). These proteins are called Ten-eleven translocation (Tet) methylcytosine dioxygenases. Based on highthroughput sequencing studies on embryonic stem cells as well as neurons from the fetal mouse hippocampus and cerebellum, 5-hmc as an epigenetic marker is thought to be associated with regulatory and intragenic regions of genes that are developmentally repressed but poised for activation (a.k.a. bivalent genes) (Szulwach et al. 2011; Gao et al. 2013). With regard to Tet enzymes, one study found that Tet1 was activity-regulated and was critical for expression of memory-associated genes and for contextual fear memory (Kaas et al. 2013). Another study, however, observed that Tet1 knockout mice exhibited normal spatial memory but had impaired fear extinction (Rudenko et al. 2013). Other Tet isoforms appear to be critical for memory as well. For example, researchers found that Tet 2 decreased in the neurons of the dentate gyrus (DG) with age and overexpressing Tet2 in DG prevented the decline in adult neurogenesis and improved CFC (Gontier et al. 2018). Another protein called Uhrf2, which is thought to be a 5 -hmc reader, appears to have some role in memory formation. Mice lacking Uhrf2 exhibit partial impairment of spatial memory (Chen et al. 2017).

\section{Other DNA modifications}

Recent studies indicate that DNA modification at nucleotides other than cytosine also play a role in certain types of memory. For example, N6-methyl-2'-deoxyadenosine accumulates at promoters and coding regions of genes in prefrontal cortical neurons of mice trained in fear extinction. Furthermore, the enzyme responsible for this DNA modification, m6dA methyltransferase (N6amt1), binds to the genomic sequences and enhanced genome-wide occupancy of N6amt1 is associated with increased gene expression. Occupancy by N6amt1 also occurs at specific promoters of genes such as that of $B d n f$ exon 4 , whose expression is correlated with extinction of conditioned fear (Li et al. 2019).

\section{Epigenetic control by small noncoding RNAs}

DNA methylation, especially of clusters of CpG sequences (CpG islands) in promoters of genes, can be brought about by small noncoding RNAs called piRNAs. Studies on Aplysia have shown that piRNAs have a role in regulating expression of genes important for long-term synaptic plasticity. The piRNAs are RNAs that were originally named because of their interaction with proteins called piwi (P-element Induced WImpy testis) in Drosophila. The piRNAs were mainly known for their role in posttranscriptional silencing of transposons in germline cells through DNA methylation. An investigation of RNA library generated from Aplysia neurons revealed the presence of piRNAs (Rajasethupathy et al. 2012). Additional studies carried out by silencing or overexpressing piwi proteins in Aplysia neurons showed that some piRNAs might silence expression of a CREB repressor called Creb2. A specific piRNA called aca-piR-F was shown to be a transcriptional regulator of Creb2. In addition, aca-piR-F was found to be up-regulated by 5-HT, the neurotransmitter critical for inducing long-term synaptic plasticity in Aplysia. It has been suggested (although not demonstrated) that aca-piR-F regulates $\mathrm{Creb} 2$ promoter by methylation in response to 5-HT thus converting a transient stimulus into an enduring epigenetic change (Rajasethupathy et al. 2012). Later studies showed the presence of piRNAs in the mammalian brain (Nandi et al. 2016). Moreover, knockdown of piwi-like genes Piwil1 and Piwil2 in the dorsal hippocampus enhances contextual fear memory (Leighton et al. 2019). 


\section{Histone modification}

Histone modification can be transcription-favoring or transcription-repressing type (Bach and Hegde 2016). Acetylation of histone on lysine residues opens the chromatin and facilitates transcription (Levenson et al. 2004). Conversely, the removal of acetyl groups by deacetylases inhibits transcription. Histone methylation on lysine residues can promote or block transcription depending on the number of methyl groups and the location of the lysine residue within the histone protein (Tables 2, 3; Gräff et al. 2012; Gupta-Agarwal et al. 2012; Bach et al. 2015).

With regard to the role of histone acetylation in memory formation, some of the early work indicated that histone acetyltransferase activity of CREB-binding protein (CBP), a transcriptional coactivator of CREB, plays a vital role in memory consolidation (Korzus et al. 2004). Subsequent evidence for a role of histone acetylation in memory came from the observations that the enzymes that remove the acetylation mark on chromatin, namely, histone deacetylases hinder long-term synaptic plasticity and impair memory (Guan et al. 2009).

Tri-methylation of histone 3 on lysine 4 (H3K4me3) is up-regulated in the hippocampus $1 \mathrm{~h}$ after CFC (Gupta et al. 2010). In addition, mice lacking $M l l$, a gene encoding a histone methyltransferase responsible for H3K4me3, exhibit impairment in CFC and performance in water maze (Kerimoglu et al. 2013). Recent studies indicate that specific histone methyltransferases control H3K4me3 in distinct genomic regions and are responsible for regulating distinct gene expression programs underlying memory consolidation (Kerimoglu et al. 2017). A transcriptionrepressing form of histone methylation (H3K27me3) has been found to have a role in memory as well. During reconsolidation of fear memory expression of Pten, a phosphatase that negatively regulates mTOR signaling, is reduced. This is achieved by an increase in H3K27me3 in the Pten promoter and coding regions (Jarome et al. 2018). The methyltransferase responsible for H3K27me3, Ezh2 has a role in adult neurogenesis and conditional knockout of the Ezh2 gene impairs spatial learning and memory (Zhang et al. 2014). Pharmacological inhibition of SUV39H1, a methyltransferase that works to add a repressive mark on histone H3 (H3K9me3), improves dendritic spine formation, increases surface GluR1 levels on spines, and improves object location memory, CFC and performance in other complex spatial learning tasks (Snigdha et al. 2016). Another histone modification, phosphoryla- tion of histone H3 on Ser-10 (H3S10ph), has been linked to an increase in transcription-dependent LTP mediated by stimulation of $\beta$-adrenergic receptors and consequent activation of Aurora kinase-B (Maity et al. 2016). Histone marks such as H3S10ph occur transiently in the hippocampus but persist in cortical areas in order to facilitate memory consolidation (Gräff et al. 2012). Some histone modifications such as demethylation of certain lysine residues (H3K9me2) function in memory consolidation by activating some genes and silencing other genes depending on whether the histone mark is at the promoter or the coding region of the gene (Table 2; Gupta-Agarwal et al. 2012). Given the role for histone modification in memory, logically the enzymes that are responsible for epigenetic marking of histones should have a role in memory-related synaptic plasticity. Indeed, numerous studies have demonstrated a role for histone-modifying and unmodifying enzymes in long-term synaptic plasticity and memory (Table 3; McQuown et al. 2011; Jing et al. 2017; Tang et al. 2017; Yamakawa et al. 2017; Schoberleitner et al. 2019; Zhu et al. 2019).

Other molecules that are part of the regulatory system for epigenetic modification have been shown to have a role in synaptic plasticity as well. Three classes of molecules called readers, erasers, and writers of chromatin modification are known to exist. A molecule belonging to the class of readers called L3mbt1 (lethal 3 malignant brain tumor-like 1) has a role in homeostatic synaptic downscaling (Mao et al. 2018). A key target of L3mbt1 is the Ctnnb1 gene. In response to synaptic activity L3mbt1 positively regulates the expression of Ctnnb1. The protein product of the Ctnnb1 gene is called $\beta$-catenin. One of the functions of $\beta$-catenin is in synaptic scaffolding at excitatory synapses. $\beta$-catenin interacts with cadherin, which bridges the pre- and postsynaptic parts of a synapse, and together they regulate synaptic structure and function.

Recent studies indicate that the accessibility of chromatin increases during learning and multiple noncoding regulatory regions are subject to modification (Koberstein et al. 2018).

\section{Translation underlying long-term synaptic plasticity and memory: initial studies}

Control of mRNA translation is one of the major ways by which the amount of protein product generated from a transcribed gene is

Table 2. Role of histone modifications in memory

\begin{tabular}{|c|c|c|c|}
\hline $\begin{array}{l}\text { Histone } \\
\text { modification }\end{array}$ & $\begin{array}{l}\text { Effect on } \\
\text { transcription }\end{array}$ & Findings & Reference(s) \\
\hline H3S10ph & Activate & $\begin{array}{l}\uparrow \text { at Zif268 promoter in HC after NOR } \\
\uparrow \text { in CA1 after HFS-induced LTP }\end{array}$ & $\begin{array}{l}\text { Gräff et al. 2012; Maity et al. } \\
2016\end{array}$ \\
\hline H3K9ac & Activate & $\uparrow$ in CA1 immediately after CLTP and sustained until $30 \mathrm{~min}$ & Bach et al. 2015 \\
\hline $\mathrm{H} 3 \mathrm{~K} 14 \mathrm{ac}$ & Activate & $\begin{array}{l}\uparrow \text { in HC after CFC in an NMDAR- and ERK-dependent manner } \\
\uparrow \text { at Zif2 } 68 \text { promoter in HC after NOR } \\
\end{array}$ & $\begin{array}{l}\text { Levenson et al. } 2004 \\
\text { Gräff et al. } 2012 \\
\text { Bach et al. } 2015\end{array}$ \\
\hline H3K4me3 & Activate & $\begin{array}{l}\uparrow \text { at Zif } 268 \text { and } B d n f \text { promoters in HC after CFC } \\
\uparrow \text { in CA } 1 \text { and EC after CFC training } \\
\uparrow \text { in CA } 1 \text { immediately after CLTP }\end{array}$ & $\begin{array}{l}\text { Gupta et al. } 2010 \\
\text { Gupta-Agarwal et al. } 2012 \\
\text { Bach et al. } 2015\end{array}$ \\
\hline H3K9me3 & Silence & $\downarrow$ after CFC and other spatial learning & Snigdha et al. 2016 \\
\hline H3K27me3 & Silence & $\begin{array}{l}\uparrow \text { at select gene promoters (e.g. Pten) during memory } \\
\text { reconsolidation }\end{array}$ & $\begin{array}{l}\text { Jarome et al. 2018; Zhang et al. } \\
2014\end{array}$ \\
\hline H3K36me3 & Activate & $\uparrow$ at Zif268 promoter in HC after NOR & Gräff et al. 2012 \\
\hline H3K9me2 & Silence & $\begin{array}{l}\uparrow \text { at Zif268, Dmnt3a, Bdnf-PIV, and c-Fos promoters in CA1 and } \\
\text { EC after CFC }\end{array}$ & Gupta-Agarwal et al. 2012 \\
\hline H2BK120ub & Activate & $\begin{array}{l}\uparrow \text { in HC after CFC } \\
\uparrow \text { in CA1 immediately after CLTP and } 30 \text { min postinduction }\end{array}$ & $\begin{array}{l}\text { Gupta et al. } 2010 \\
\text { Bach et al. } 2015\end{array}$ \\
\hline
\end{tabular}

CA1, cornu ammonis 1; CFC, contextual fear conditioning; CLTP, chemically induced LTP; EC, entorihinal cortex; HC, hippocampus; HFS, high frequency stimulation; NOR, novel object recognition task. 
Table 3. Role of histone modifying proteins in memory

\begin{tabular}{|c|c|c|c|c|}
\hline Molecule & Function & Model & Findings & Reference(s) \\
\hline $\begin{array}{l}\text { Aurora } \\
\text { kinase B }\end{array}$ & Histone kinase & Chemical inhibition & $\begin{array}{l}\downarrow \text { H3S10ph levels in CA1 associated with noradrenaline/ } \\
\text { HFS-induced LTP }\end{array}$ & $\begin{array}{l}\text { Maity et al. } \\
2016\end{array}$ \\
\hline Chd1 & $\mathrm{H} 3 \mathrm{~K} 4 \mathrm{me}$ regulation & Chd1 deletion & $\begin{array}{l}\downarrow \text { performance in NOR and Barnes maze } \\
\downarrow \text { Egr1 and Arc expression in HC }\end{array}$ & $\begin{array}{l}\text { Schoberleitner } \\
\text { et al. } 2019\end{array}$ \\
\hline Ezh2 & Histone methyltransferase & Ezh2 KO & $\downarrow$ performance in MWM, cued fear learning, and CFC & $\begin{array}{l}\text { Zhang et al. } \\
2014\end{array}$ \\
\hline G9a/GLP & Histone methyltransferase & $\begin{array}{l}\text { CA1 chemical inhibition } \\
\text { EC chemical inhibition }\end{array}$ & $\begin{array}{l}\downarrow \text { LTP facilitation and performance in CFC } \\
\uparrow \text { LTP facilitation and performance in CFC } \\
\downarrow \text { H } 3 \text { K9me } 2 \text { at Zif } 268 \text { and Bdnf-PII promoters in CA } 1\end{array}$ & $\begin{array}{l}\text { Gupta-Agarwal } \\
\text { et al. } 2012\end{array}$ \\
\hline \multirow[t]{3}{*}{ HDAC1 } & \multirow[t]{3}{*}{ Histone deacetylase } & HDAC2 KO & $\begin{array}{l}\uparrow \text { performance in CFC, cued fear learning, MWM, and T-maze } \\
\uparrow \text { number of functional excitatory synapses and spine density } \\
\text { in CA1 } \\
\uparrow \text { LTP magnitude in HC } \\
\uparrow \text { histone acetylation at ERGs (Bdnf-PII, c-Fos, Egr1) }\end{array}$ & $\begin{array}{l}\text { Guan et al. } \\
\text { 2009; Morris } \\
\text { et al. } 2013\end{array}$ \\
\hline & & Hdac2 KD & $\uparrow$ EPSP in cultured neurons & $\begin{array}{l}\text { Yamakawa et al. } \\
2017\end{array}$ \\
\hline & & HDAC2 KI & $\begin{array}{l}\downarrow \text { performance in CFC, cued fear learning, MWM, and T-maze } \\
\downarrow \text { spine density in CA1 } \\
\downarrow \text { LTP magnitude in HC }\end{array}$ & $\begin{array}{l}\text { Guan et al. } \\
2009\end{array}$ \\
\hline \multirow[t]{3}{*}{ HDAC3 } & \multirow[t]{3}{*}{ Histone deacetylase } & - & $\downarrow N r 4 a 2$ expression in $\mathrm{HC}$ & $\begin{array}{l}\text { Kwapis et al. } \\
2019\end{array}$ \\
\hline & & HDAC3 KO & $\begin{array}{l}\uparrow \text { performance in object recognition memory task } \\
\downarrow \text { H4K8ac levels in } \mathrm{HC} \\
\uparrow c \text {-Fos and Nr4a2 expression in } \mathrm{HC}\end{array}$ & \multirow[t]{2}{*}{$\begin{array}{l}\text { McQuown et al. } \\
2011\end{array}$} \\
\hline & & HC chemical inhibition & $\begin{array}{l}\uparrow \text { performance in object recognition memory task } \\
\downarrow \text { HDAC4 levels in HC } \\
\uparrow \mathrm{H} 4 \mathrm{~K} 8 \mathrm{ac} \text { levels in } \mathrm{HC}\end{array}$ & \\
\hline \multirow[t]{3}{*}{ HDAC4/5 } & \multirow[t]{3}{*}{ Histone deacetylase } & - & $\uparrow$ HDAC4 nuclear translocation transiently after CFC in CA1 & \multirow[t]{3}{*}{ Zhu et al. 2019} \\
\hline & & $\begin{array}{l}\text { HDAC } 4 / 5-3 S A \\
\text { mutation }\end{array}$ & $\begin{array}{l}\downarrow \text { expression of ERGs (Nra41, Nra43, Arc, Npas4) due to } \\
\text { impaired nuclear export }\end{array}$ & \\
\hline & & HDAC4/5 DKO & $\begin{array}{l}\downarrow \text { performance in CFC and Barnes maze } \\
\uparrow \text { expression of ERGs after CFC in HC }\end{array}$ & \\
\hline HDAC7 & Histone deacetylase & - & $\downarrow$ levels in HC after CFC via interaction with CBX4 E3 ligase & Jing et al. 2017 \\
\hline \multirow[t]{2}{*}{ KMT2A } & \multirow[t]{2}{*}{ Histone methyltransferase } & KMT2A KO & $\downarrow$ performance in CFC and MWM & \multirow{2}{*}{$\begin{array}{l}\text { Kerimoglu et al. } \\
2013,2017\end{array}$} \\
\hline & & & $\begin{array}{l}\downarrow \mathrm{H} 3 \mathrm{~K} 4 \mathrm{me} 3 \text { at ERG (functions in transcription, chromatin, and } \\
\text { mRNA regulation and protein ubiquitination) promoters in } \\
\text { HC }\end{array}$ & \\
\hline КМТ2В & Histone methyltransferase & КМТ2В КО & $\begin{array}{l}\downarrow \text { performance in CFC, NOR, and MWM } \\
\downarrow \text { H3K4me } 3 \text { at ERG (related to synaptic plasticity) promoters } \\
\text { in HC }\end{array}$ & $\begin{array}{l}\text { Kerimoglu et al. } \\
2013\end{array}$ \\
\hline \multirow[t]{2}{*}{ L3MBTL1 } & \multirow[t]{2}{*}{$\begin{array}{l}\text { Regulator of methylated } \\
\text { lysine histone residues }\end{array}$} & - & $\begin{array}{l}\downarrow \text { levels during neural activity (PTX-induced) in HC by means } \\
\text { of proteasome degradation }\end{array}$ & \multirow[t]{2}{*}{ Mao et al. 2018} \\
\hline & & L3MBTL1 KO & $\begin{array}{l}\downarrow \text { Ctnnb1 and Gabra2 expression in HC causing impaired } \\
\text { synaptic downscaling }\end{array}$ & \\
\hline Sp3 & HDAC2 regulation & $\begin{array}{l}\text { Sp3 KD } \\
\text { HDAC2 C-terminal OE }\end{array}$ & $\begin{array}{l}\uparrow \text { EPSP in cultured neurons } \\
\uparrow \text { ERG (role in ion transport and regulation of membrane } \\
\text { proteins and receptors) expression } \\
\downarrow \text { HDAC2 binding to and facilitating } \mathrm{H} 4 \mathrm{~K} 5 \mathrm{ac} \text { and } \mathrm{H} 2 \mathrm{BK} 2 \mathrm{ac} \\
\text { levels at gene promoters }\end{array}$ & $\begin{array}{l}\text { Yamakawa et al. } \\
2017\end{array}$ \\
\hline SUV39H1 & Histone methyltransferase & Chemical inhibition & $\begin{array}{l}\uparrow \text { performance in object location memory task and CFC } \\
\text { associated with } \downarrow \mathrm{H} 3 \mathrm{~K} 9 \mathrm{me} 3 \text { levels in HC }\end{array}$ & $\begin{array}{l}\text { Snigdha et al. } \\
2016\end{array}$ \\
\hline UTX & H3K27me3 demethylase & UTX KO & $\begin{array}{l}\downarrow \text { performance in MWM } \\
\downarrow \text { PSD-95 levels and dendritic arborization } \\
\downarrow \text { ERG expression (functions in neurite elongation and } \\
\text { dendritic synaptic) formation (Egr3, Wnt4) in CA1 } \\
\uparrow \text { H3K27me3 levels in HC leads to } \downarrow H t r 5 b \text { expression, which } \\
\text { is involved in neural structural formation }\end{array}$ & Tang et al. 2017 \\
\hline
\end{tabular}

CA1, cornu ammonis 1; CFC, contextual fear conditioning; CLTP, chemically-induced LTP; EC, entorhinal cortex; ERG, early response genes; HC, hippocampus; HFS, high frequency stimulation; MWM, Morris water maze; NOR, novel object recognition task.

regulated. The bulk of early work on translational control of mRNAs relevant to synaptic plasticity and memory falls into two major lines of investigation. The first is modulation of mRNA translation through factors that interact with the $5^{\prime}$ UTR and the other is through pathways that regulate translation via interaction with the 3' UTR.

\section{Translational control at the $5^{\prime}$ UTR}

Eukaryotic mRNAs possess a 7-methyl-Guanosine $\left(\mathrm{m}^{7}-\mathrm{G}\right)$ cap. Translation of mRNAs can be controlled in a cap-dependent as well as cap-independent manner. Thus far, research on translational control underlying synaptic plasticity and memory has been mainly on the mechanisms that are cap-dependent. 
A translation preinitiation complex consists of a tRNA that binds to the initiation codon for methionine (Met-tRNA) and a eukaryotic initiation factor eIF2 bound to guanosine triphosphate. The assembly of this complex is facilitated by other initiation factors. Attachment of this complex to the $\mathrm{m}^{7}-\mathrm{G}$ cap is added by the eIF4F complex comprising eIF4E, eIF4G, and eIF4A (Hinnebusch et al. 2016).

eIF2 is phosphorylated by a protein kinase called Gcn2 which negatively regulates its function. As a result, general translation is inhibited but translation of specific mRNAs is facilitated. In the nervous system, this process facilitates the translation of Atf 4 which is a CREB repressor. As expected in mice lacking Gcn2, L-LTP which is transcription-dependent, is induced with only one train of $100 \mathrm{~Hz}$ stimulation whereas in normal mice it takes four $100 \mathrm{~Hz}$ trains to induce L-LTP. The Gcn2 (-/-) mice show memory improvement with weak training and memory impairment with strong training. Therefore, an interpretation of these results is that translational control indirectly regulates transcription and Gcn2 (-/-) mice might have too much gene expression which has an adverse effect on memory (Costa-Mattioli et al. 2005).

A role for regulation by translational elongation factor has been described as well. In Aplysia sensory neurons, which make synapses with motor neurons, elongation factor eEF1A mRNA is transported along the axon to stimulated synapses. This kind of mRNA transport is thought to link transcription at the nucleus to local protein synthesis at the synapse to promote synaptic growth (Giustetto et al. 2003).

\section{Translational control at the $\mathbf{3}^{\prime}$ UTR}

Translation of eukaryotic mRNAs depends on the extent of polyadenylation at the $3^{\prime}$ UTR. A key molecule that regulates lengthened Poly(A)-tail-dependent translation is Cytoplasmic Polyadenylation Element Binding Protein (CPEB). The mRNAs subject to regulation by CPEB contain Cytoplasmic Polyadenylation Element (CPE) which comprises a consensus sequence UUUUUAU. When the RNA transcribed in the nucleus is exported to the cytoplasm, CPEB binds to CPE and a ribonucleoprotein (RNP) assembly containing CPEB and other proteins forms. This RNP can keep the Poly(A) short because of the presence of a deadenylating enzyme. Alternatively, when CPEB is phosphorylated by Aurora kinase, the deadenylating enzyme is pushed out of the RNP complex which now elongates the Poly(A)-tail and thus promotes translation (Darnell and Richter 2012).

A role for CPEB in translation required for long-term synaptic plasticity was found in the invertebrate Aplysia. In the sensorymotor neuron synapses reconstituted in culture, the researchers found that injection of antisense oligonucleotides against an isoform of CPEB called CPEB2 inhibited long-term facilitation ( $\mathrm{Si}$ et al. 2003a). It was proposed that CPEB might sustain its function because of its prion-like properties (Si et al. 2003b). A mammalian CPEB isoform, CPEB3, regulates protein synthesis required for hippocampus-based memory. Subsequent work showed that attachment of small-ubiquitin-like modifier (SUMO) to CPEB3 negatively regulates its prion-like aggregation (Drisaldi et al. 2015). It remains to be seen whether prion-like aggregation is a peculiarity of some CPEB isoforms because no other molecule with a role in memory with prion-like properties has been reported.

\section{Regulation of translation by microRNAs during synaptic plasticity and memory}

MicroRNAs are small noncoding RNAs typically 21-nt long. They bind to complementary sequences and negatively regulate translation by causing degradation of mRNAs or suppressing their translation. For example, miR-26a and miR-384-5p generally suppress the expression of ribosomal S6 kinase 3 which is a translational regulator. These microRNAs are down-regulated during NMDARdependent LTP thereby increasing the translation of S6 kinase which in turn boosts the translation required for making LTP last long. A microRNA regulated by activity, miR-188, decreases the expression of a glycoprotein Neuropilin- 2 which functions as a receptor for semaphorin $3 \mathrm{~F}$, a negative regulator of spine development (Lee et al. 2012). Another example is miR-22 in presynaptic sensory neurons of Aplysia which negatively regulates CPEB. Upon stimulation that induces LTF, the miR-22-imposed constraint on CPEB translation is relieved and its expression increases. Augmented levels of CPEB lead to other molecular events, such as an increase in a specific atypical protein kinase $\mathrm{C}$ isoform, causing synapses to strengthen (Fiumara et al. 2015).

In terms of linking miRNAs to memory, global loss of miRNAs through deletion of Dicer1, which encodes a protein that is part of miRNA generation, causes enhancement of memory as measured by Morris water maze, trace fear conditioning and other tests of cognition (Konopka et al. 2010). Another microRNA is miR-132 which was originally found to control neuronal morphogenesis. Since then, a role of miR-132 in synaptic plasticity and memory has been shown. Transgenic mice expressing miR-132 at various levels showed that expression of this microRNA might be related to cognitive capacity (Hansen et al. 2013). Other studies showed a role for miR-132 in recognition memory that depends on synaptic plasticity in the perirhinal cortex (Scott et al. 2012).

Overexpression of miR-181c ameliorates cognitive impairment caused by chronic hypoperfusion in rats. This study found that miR-181c regulates the expression of TRIM2 which is a ubiquitin ligase that targets neurofilament light (NF-L) protein. Increased expression of miR-181c therefore ultimately led to enhanced expression of NF-L which in turn correlated with increased dendritic arborization and spine formation (Fang et al. 2017).

RNA-induced silencing complex (RISC) appears to play a role in synaptic protein synthesis in the circuitry underlying olfactory memory in Drosophila. Normally in the second order synapses mRNA translation is silenced by Armitage, an RNA helicase and a component of the RISC complex (Ashraf et al. 2006). During longterm memory formation, Armitage in degraded in a proteasomedependent manner thus relieving the repression of translation by RISC. This mechanism seems to be evolutionarily conserved. When a key component of the RISC complex called Argonaute is down-regulated using a pool of siRNAs in the dorsal hippocampus of C57BL/6 mice, short- as well as long-term contextual memory is impaired (Batassa et al. 2010). From these studies, it is not clear how short-term memory is affected by reduction in translation. Additional investigation such as electrophysiological experiments to measure synaptic plasticity might help elucidate mechanistic links between RISC function and memory in mammals.

\section{Regulation of miRNAs}

miRNAs themselves are subject to transcriptional regulation. Previous studies showed that some miRNAs are subject to control by CREB. For example, miR-132 was identified as a target of CREB through a genome-wide screen (Vo et al. 2005). Expression of miR-132 has been shown to be regulated by neuronal activity in different brain regions and in the hippocampus by CFC (Nudelman et al. 2010). Although activation of microRNAs by specific transcription factors has not been studied widely, this type of activation might be important for expression of specific set of genes during memory formation.

miRNA expression might also be controlled more broadly as well. A gene implicated in schizophrenia Satb2 encodes a transcriptional regulator which appears to control the expression of a large set of miRNAs. Satb2 protein is expressed in the cerebral cortex and 
the CA1 region of the hippocampus. Forebrain-specific deletion of Satb2 impairs maintenance of L-LTP and long-term contextual fear memory as well as object discrimination memory (Jaitner et al. 2016).

\section{Role of long noncoding RNAs (IncRNAs) in translation}

Recently, a nucleolus-specific long noncoding RNA (LoNA) has been identified by high-throughput sequencing. This LoNA is mainly expressed in neurons and plays a role in ribosomal RNA (rRNA) transcription and posttranscriptional modification. Normally, LoNA represses rRNA biogenesis and in response to neuronal activity its levels decrease leading to an increase in rRNA and translation of mRNAs. LoNA deficiency leads to improved learning and memory and conversely when its levels are increased it impairs memory (Li et al. 2018).

\section{Local mRNA translation: latest findings}

A key aspect of synapse-specificity of long-term plasticity that underlies memory is local translation of preexisting mRNAs. The importance of local translation during LTF in Aplysia and LTP in the hippocampus was shown several years ago (Frey and Morris 1997; Martin et al. 1997). Evidence for local translation continues to be accumulated. For example, a recent study showed the importance of Fragile X Mental Retardation Protein (FMRP) in regulating local dendritic translation of the $\alpha$ subunit of calcium-calmodulindependent protein kinase during an olfactory learning task that required the newborn neurons in the olfactory bulb (Daroles et al. 2016).

The mRNAs themselves are localized in dendrites which can provide spatial restriction of translation even within subregions of dendrites such as the shafts or spines (Van Driesche and Martin 2018). The recent data show that the mechanisms such as regulation through miRNAs can also be localized in dendrites as well. For example, Dicer and pre-miRNAs are localized at dendrites or in proximity to synapses. Investigation on miR-181a using a probe that increased its fluorescence upon processing by Dicer showed that miR-181a matured locally in dendrites in response to neuronal activity at individual synapses (Sambandan et al. 2017).

\section{Translational control by protein degradation during formation of synaptic plasticity and memory}

Apart from regulation by posttranslational modification the translation factors can be regulated by degradation by the UPP. During L-LTP, proteasome-mediated degradation controls the amounts of the initiation factor eIF4E and the elongation factor eEF1A. In addition, the proteasome also modulates the amount of translation repressors such as Paip2 and 4E-BP (Dong et al. 2014a).

Proteolysis also regulates translation by modulating the factors that interact with the $3^{\prime}$ UTR. Although CPEB is a substrate for the proteasome (Reverte et al. 2001), the effect of its degradation has not been studied so far. However, the proteasome has been shown to limit signaling in the cytoplasmic polyadenylation pathway during L-LTP (Dong et al. 2014b).

Other studies have shown that FMRP which acts as a translational repressor in the cytoplasm is a substrate for the ubiquitin ligase Cdh1-APC (anaphase promoting complex). In Cdh1 knockout mice mGluR-dependent LTD is impaired (Huang et al. 2015).

\section{Future prospects}

Research on transcriptional and translational regulation is likely to advance on two fronts. One is the quest for additional proteins and regulatory mechanisms that are critical for transcription and translation during formation and maintenance of long-term synaptic plasticity and memory. The researchers might be aided by advances elsewhere. For example, analysis of public high-throughput data using machine learning led to the identification of a new gene called Grunge/Atrophin important for social learning in Drosophila (Kacsoh et al. 2017). The big data approach is being applied to the study of RNAs which should help researchers to ask new questions about translational regulation as well. For example, subcellular sequencing from single mouse neurons revealed the presence of 2225 dendritic RNAs (Middleton et al. 2019). The second front of advancement should be in making sense of the data on transcription and translation. Computational approach combined with pharmacological intervention is helping make testable predictions with regard to LTF in Aplysia sensory-motor neuron synapses. For example, researchers knocked down Creb1 with siRNA and rescued the impaired LTF by using a training protocol predicted to be successful by computational approach (Zhou et al. 2015). Another example is a study using the Caenorhabditis elegans model in which investigators identified $757 \mathrm{CREB} /$ memory-induced targets by combining memory-training and gene expression analysis (Lakhina et al. 2015). The challenge for the future is to devise such approaches to mammalian models and ultimately to humans to fully understand long-term synaptic plasticity and memory and possibly develop drugs to treat memory deficits.

\section{Acknowledgments}

This work was supported by a grant to A.N.H. from National Institute of Neurological Disease and Stroke (NINDS) (NS 098405).

\section{References}

Ahn HJ, Hernandez CM, Levenson JM, Lubin FD, Liou HC, Sweatt JD. 2008

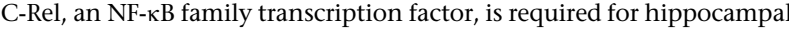
long-term synaptic plasticity and memory formation. Learn Mem 15: 539-549. doi:10.1101/lm.866408

Alexander JC, McDermott CM, Tunur T, Rands V, Stelly C, Karhson D, Bowlby MR, An WF, Sweatt JD, Schrader LA. 2009. The role of calsenilin/ DREAM/KChIP3 in contextual fear conditioning. Learn Mem 16: 167-177. doi:10.1101/lm.1261709

Araujo DJ, Toriumi K, Escamilla CO, Kulkarni A, Anderson AG, Harper M, Usui N, Ellegood J, Lerch JP, Birnbaum SG, et al. 2017. Foxp1 in forebrain pyramidal neurons controls gene expression required for spatial learning and synaptic plasticity. J Neurosci 37: 10917-10931. doi:10 1523/JNEUROSCI.1005-17.2017

Ashraf SI, McLoon AL, Sclarsic SM, Kunes S. 2006. Synaptic protein synthesis associated with memory is regulated by the RISC pathway in Drosophila. Cell 124: 191-205. doi:10.1016/j.cell.2005.12.017

Bach SV, Hegde AN. 2016. The proteasome and epigenetics: zooming in on histone modifications. Biomol Concepts 7: 215-227. doi:10.1515/ bmc-2016-0016

Bach SV, Tacon PR, Morgan JW, Hegde AN. 2015. Proteasome regulates transcription-favoring histone methylation, acetylation and ubiquitination in long-term synaptic plasticity. Neurosci Lett 591: 5964. doi:10.1016/j.neulet.2015.02.029

Bartsch D, Ghirardi M, Skehel PA, Karl KA, Herder SP, Chen M, Bailey CH, Kandel ER. 1995. Aplysia CREB2 represses long-term facilitation: relief of repression converts transient facilitation into long-term functional and structural change. Cell 83: 979-992. doi:10.1016/0092-8674(95) 90213-9

Bartsch D, Casadio A, Karl KA, Serodio P, Kandel ER. 1998. CREB1 encodes a nuclear activator, a repressor, and a cytoplasmic modulator that form a regulatory unit critical for long-term facilitation. Cell 95: 211-223. doi:10.1016/S0092-8674(00)81752-3

Batassa EM, Costanzi M, Saraulli D, Scardigli R, Barbato C, Cogoni C, Cestari V. 2010. Risc activity in hippocampus is essential for contextual memory. Neurosci Lett 471: 185-188. doi:10.1016/j.neulet.2010.01.038 
Bourtchuladze R, Frenguelli B, Blendy J, Cioffi D, Schutz G, Silva AJ. 1994. Deficient long-term memory in mice with a targeted mutation of the cAMP-responsive element-binding protein. Cell 79: 59-68. doi:10.1016/ 0092-8674(94)90400-6

Bridi MS, Abel T. 2013. The nR4A orphan nuclear receptors mediate transcription-dependent hippocampal synaptic plasticity. Neurobiol Learn Mem 105: 151-158. doi:10.1016/j.nlm.2013.06.020

Bridi MS, Hawk JD, Chatterjee S, Safe S, Abel T. 2017. Pharmacological activators of the NR4A nuclear receptors enhance LTP in a CREB/ CBP-dependent manner. Neuropsychopharmacology 42: 1243. doi:10 $.1038 /$ npp.2016.253

Chen A, Muzzio IA, Malleret G, Bartsch D, Verbitsky M, Pavlidis P, Yonan AL, Vronskaya S, Grody MB, Cepeda I, et al. 2003. Inducible enhancement of memory storage and synaptic plasticity in transgenic mice expressing an inhibitor of ATF4 (CREB-2) and C/EBP proteins. Neuron 39: 655-669. doi:10.1016/S0896-6273(03)00501-4

Chen R, Zhang Q, Duan X, York P, Chen GD, Yin P, Zhu H, Xu M, Chen P, $\mathrm{Wu} \mathrm{Q}$, et al. 2017. The 5-hydroxymethylcytosine $(5 \mathrm{hmc})$ reader UHRF2 is required for normal levels of $5 \mathrm{hmc}$ in mouse adult brain and spatial learning and memory. J Biol Chem 292: 4533-4543. doi:10.1074/jbc M116.754580

Ch'ng TH, Uzgil B, Lin P, Avliyakulov NK, O'Dell TJ, Martin KC. 2012. Activity-dependent transport of the transcriptional coactivator crtc1 from synapse to nucleus. Cell 150: 207-221. doi:10.1016/j.cell.2012.05 .027

Cole CJ, Mercaldo V, Restivo L, Yiu AP, Sekeres MJ, Han JH, Vetere G, Pekar T, Ross PJ, Neve RL, et al. 2012. MEF2 negatively regulates learning-induced structural plasticity and memory formation. Nat Neurosci 15: 1255-1264. doi:10.1038/nn.3189

Costa-Mattioli M, Gobert D, Harding H, Herdy B, Azzi M, Bruno M, Bidinosti M, Ben Mamou C, Marcinkiewicz E, Yoshida M, et al. 2005. Translational control of hippocampal synaptic plasticity and memory by the eIF2 $\alpha$ kinase GCN2. Nature 436: 1166-1173. doi:10.1038/ nature03897

Darnell JC, Richter JD. 2012. Cytoplasmic RNA-binding proteins and the control of complex brain function. Cold Spring Harb Perspect Biol 4: a012344. doi:10.1101/cshperspect.a012344

Daroles L, Gribaudo S, Doulazmi M, Scotto-Lomassese S, Dubacq C, Mandairon N, Greer CA, Didier A, Trembleau A, Caillé I. 2016. Fragile X mental retardation protein and dendritic local translation of the $\alpha$ subunit of the calcium/calmodulin-dependent kinase ii messenger RNA are required for the structural plasticity underlying olfactory learning. Biol Psychiatry 80: 149-159. doi:10.1016/j.biopsych.2015.07.023

Dash PK, Hochner B, Kandel ER. 1990. Injection of the cAMP-responsive element into the nucleus of Aplysia sensory neurons blocks long-term facilitation. Nature 345: 718-721. doi:10.1038/345718a0

Dash PK, Orsi SA, Moore AN. 2005. Sequestration of serum response factor in the hippocampus impairs long-term spatial memory. J Neurochem 93: 269-278. doi:10.1111/j.1471-4159.2004.03016.x

Dong C, Upadhya SC, Ding L, Smith TK, Hegde AN. 2008. Proteasome inhibition enhances the induction and impairs the maintenance of late-phase long-term potentiation. Learn Mem 15: 335-347. doi:10 $.1101 / \mathrm{lm} .984508$

Dong C, Bach SV, Haynes KA, Hegde AN. 2014a. Proteasome modulates positive and negative translational regulators in long-term synaptic plasticity. J Neurosci 34: 3171-3182. doi:10.1523/JNEUROSCI.3291-13 .2014

Dong C, Vashisht A, Hegde AN. 2014b. Proteasome regulates the mediators of cytoplasmic polyadenylation signaling during late-phase long-term potentiation. Neurosci Lett 583: 199-204. doi:10.1016/j.neulet.2014.09 .038

Drisaldi B, Colnaghi L, Fioriti L, Rao N, Myers C, Snyder AM, Metzger DJ, Tarasoff J, Konstantinov E, Fraser PE, et al. 2015. Sumoylation is an inhibitory constraint that regulates the prion-like aggregation and activity of CPEB3. Cell Rep 11: 1694-1702. doi:10.1016/j.celrep.2015.04 .061

Etkin A, Alarcón JM, Weisberg SP, Touzani K, Huang YY, Nordheim A, Kandel ER. 2006. A role in learning for SRF: deletion in the adult forebrain disrupts ltd and the formation of an immediate memory of a novel context. Neuron 50: 127-143. doi:10.1016/j.neuron.2006.03.013

Fang C, Li Q, Min G, Liu M, Cui J, Sun J, Li L. 2017. MicroRNA-181c ameliorates cognitive impairment induced by chronic cerebral hypoperfusion in rats. Mol Neurobiol 54: 8370-8385. doi:10.1007/ s12035-016-0268-6

Fiumara F, Rajasethupathy P, Antonov I, Kosmidis S, Sossin WS, Kandel ER. 2015. MicroRNA-22 gates long-term heterosynaptic plasticity in Aplysia through presynaptic regulation of CPEB and downstream targets. Cell Rep 11: 1866-1875. doi:10.1016/j.celrep.2015.05.034

Flexner LB, Flexner JB, De La Haba G, Roberts RB. 1965. Loss of memory as related to inhibition of cerebral protein synthesis. J Neurochem 12: 535541. doi:10.1111/j.1471-4159.1965.tb04246.x
Fontán-Lozano A, Romero-Granados R, del-Pozo-Martín Y, Suárez-Pereira I, Delgado-García JM, Penninger JM, Carrión AM. 2009. Lack of dream protein enhances learning and memory and slows brain aging. Curr Biol 19: 54-60. doi:10.1016/j.cub.2008.11.056

Frey U, Morris RG. 1997. Synaptic tagging and long-term potentiation. Nature 385: 533-536. doi:10.1038/385533a0

Gao F, Xia Y, Wang J, Luo H, Gao Z, Han X, Zhang J, Huang X, Yao Y, Lu H, et al. 2013. Integrated detection of both 5-mc and 5-hmc by high-throughput tag sequencing technology highlights methylation reprogramming of bivalent genes during cellular differentiation. Epigenetics 8: 421-430. doi:10.4161/epi.24280

Giustetto M, Hegde AN, Si K, Casadio A, Inokuchi K, Pei W, Kandel ER, Schwartz JH. 2003. Axonal transport of eukaryotic translation elongation factor $1 \alpha$ mRNA couples transcription in the nucleus to long-term facilitation at the synapse. Proc Natl Acad Sci 100: 1368013685. doi:10.1073/pnas. 1835674100

Gontier G, Iyer M, Shea JM, Bieri G, Wheatley EG, Ramalho-Santos M, Villeda SA. 2018. Tet2 rescues age-related regenerative decline and enhances cognitive function in the adult mouse brain. Cell Rep 22: 1974-1981. doi:10.1016/j.celrep.2018.02.001

Gräff J, Woldemichael BT, Berchtold D, Dewarrat G, Mansuy IM. 2012. Dynamic histone marks in the hippocampus and cortex facilitate memory consolidation. Nat Commun 3: 991. doi:10.1038/ncomms1997

Guan J-S, Haggarty SJ, Giacometti E, Dannenberg J-H, Joseph N, Gao J, Nieland TJ, Zhou Y, Wang X, Mazitschek R. 2009. HDAC2 negatively regulates memory formation and synaptic plasticity. Nature 459: 55. doi:10.1038/nature07925

Gupta S, Kim SY, Artis S, Molfese DL, Schumacher A, Sweatt JD, Paylor RE, Lubin FD. 2010. Histone methylation regulates memory formation. J Neurosci 30: 3589-3599. doi:10.1523/JNEUROSCI.3732-09.2010

Gupta-Agarwal S, Franklin AV, Deramus T, Wheelock M, Davis RL, McMahon LL, Lubin FD. 2012. G9a/GLP histone lysine dimethyltransferase complex activity in the hippocampus and the entorhinal cortex is required for gene activation and silencing during memory consolidation. J Neurosci 32: 5440-5453. doi:10.1523/ JNEUROSCI.0147-12.2012

Hansen KF, Karelina K, Sakamoto K, Wayman GA, Impey S, Obrietan K. 2013. miRNA-132: a dynamic regulator of cognitive capacity. Brain Struct Funct 218: 817-831. doi:10.1007/s00429-012-0431-4

Hawk JD, Bookout AL, Poplawski SG, Bridi M, Rao AJ, Sulewski ME, Kroener BT, Manglesdorf DJ, Abel T. 2012. Nr4a nuclear receptors support memory enhancement by histone deacetylase inhibitors. J Clin Invest 122: 3593-3602. doi:10.1172/JCI64145

Hinnebusch AG, Ivanov IP, Sonenberg N. 2016. Translational control by 5'-untranslated regions of eukaryotic mRNAs. Science 352: 1413-1416. doi:10.1126/science.aad9868

Huang J, Ikeuchi Y, Malumbres M, Bonni A. 2015. A Cdh1-APC/FMRP ubiquitin signaling link drives mGluR-dependent synaptic plasticity in the mammalian brain. Neuron 86: 726-739. doi:10.1016/j.neuron.2015 .03 .049

Jaitner C, Reddy C, Abentung A, Whittle N, Rieder D, Delekate A, Korte M, Jain G, Fischer A, Sananbenesi F, et al. 2016. Satb2 determines miRNA expression and long-term memory in the adult central nervous system. Elife 5: e17361. doi:10.7554/eLife.17361

Jarome TJ, Perez GA, Hauser RM, Hatch KM, Lubin FD. 2018. EZH2 methyltransferase activity controls Pten expression and mTOR signaling during fear memory reconsolidation. J Neurosci 38: 7635-7648. doi:10 .1523/JNEUROSCI.0538-18.2018

Jing X, Sui W-H, Wang S, Xu X-F, Yuan RR, Chen XR, Ma HX, Zhu YX, Sun JK, Yi F. 2017. HDAC7 ubiquitination by the E3 ligase CBX4 is involved in contextual fear conditioning memory formation. J Neurosci 37: 3848-3863. doi:10.1523/JNEUROSCI.2773-16.2017

Kaas GA, Zhong C, Eason DE, Ross DL, Vachhani RV, Ming GL, King JR, Song H, Sweatt JD. 2013. TET1 controls CNS 5-methylcytosine hydroxylation, active DNA demethylation, gene transcription, and memory formation. Neuron 79: 1086-1093. doi:10.1016/j.neuron.2013 .08 .032

Kacsoh BZ, Greene CS, Bosco G. 2017. Machine learning analysis identifies Drosophila grunge/atrophin as an important learning and memory gene required for memory retention and social learning. G3 (Bethesda) 7: 3705-3718. doi:10.1534/g3.117.300172

Kandel ER. 2012. The molecular biology of memory: cAMP, PKA, CRE, CREB-1, CREB-2, and CPEB. Mol Brain 5: 14. doi:10.1186/ 1756-6606-5-14

Kerimoglu C, Agis-Balboa RC, Kranz A, Stilling R, Bahari-Javan S, Benito-Garagorri E, Halder R, Burkhardt S, Stewart AF, Fischer A. 2013. Histone-methyltransferase MLL2 (KMT2B) is required for memory formation in mice. J Neurosci 33: 3452-3464. doi:10.1523/JNEUROSCI $.3356-12.2013$

Kerimoglu C, Sakib MS, Jain G, Benito E, Burkhardt S, Capece V, Kaurani L, Halder R, Agís-Balboa RC, Stilling R. 2017. KMT2A and KMT2B mediate 
memory function by affecting distinct genomic regions. Cell Rep 20: 538-548. doi:10.1016/j.celrep.2017.06.072

Koberstein JN, Poplawski SG, Wimmer ME, Porcari G, Kao C, Gomes B, Risso D, Hakonarson H, Zhang NR, Schultz RT, et al. 2018. Learning-dependent chromatin remodeling highlights noncoding regulatory regions linked to autism. Sci Signal 11: eaan6500. doi:10 $.1126 /$ scisignal.aan6500

Konopka W, Kiryk A, Novak M, Herwerth M, Parkitna JR, Wawrzyniak M, Kowarsch A, Michaluk P, Dzwonek J, Arnsperger T, et al. 2010. MicroRNA loss enhances learning and memory in mice. J Neurosci 30: 14835-14842. doi:10.1523/JNEUROSCI.3030-10.2010

Korzus E, Rosenfeld MG, Mayford M. 2004. CBP histone acetyltransferase activity is a critical component of memory consolidation. Neuron 42: 961-972. doi:10.1016/j.neuron.2004.06.002

Kwapis JL, Alaghband Y, López AJ, Long JM, Li X, Shu G, Bodinayake KK, Matheos DP, Rapp PR, Wood MA. 2019. HDAC3-mediated repression of the $\mathrm{Nr} 4 a$ family contributes to age-related impairments in long-term memory. J Neurosci 39: 4999-5009. doi:10.1523/JNEUROSCI.2799-18 .2019

Lakhina V, Arey RN, Kaletsky R, Kauffman A, Stein G, Keyes W, Xu D, Murphy CT. 2015. Genome-wide functional analysis of CREB/long-term memory-dependent transcription reveals distinct basal and memory gene expression programs. Neuron 85: 330-345. doi:10.1016/j.neuron .2014 .12 .029

Leach PT, Poplawski SG, Kenney JW, Hoffman B, Liebermann DA, Abel T, Gould TJ. 2012. Gadd45b knockout mice exhibit selective deficits in hippocampus-dependent long-term memory. Learn Mem 19: 319-324. doi:10.1101/lm.024984.111

Lee K, Kim JH, Kwon OB, An K, Ryu J, Cho K, Suh YH, Kim HS. 2012. An activity-regulated microRNA, miR-188, controls dendritic plasticity and synaptic transmission by downregulating neuropilin-2. J Neurosci 32: 5678-5687. doi:10.1523/JNEUROSCI.6471-11.2012

Leighton LJ, Wei W, Marshall PR, Ratnu VS, Li X, Zajaczkowski EL, Spadaro PA, Khandelwal N, Kumar A, Bredy TW. 2019. Disrupting the hippocampal piwi pathway enhances contextual fear memory in mice. Neurobiol Learn Mem 161: 202-209. doi:10.1016/j.nlm.2019.04.002

Levenson JM, O'Riordan KJ, Brown KD, Trinh MA, Molfese DL, Sweatt JD. 2004. Regulation of histone acetylation during memory formation in the hippocampus. J Biol Chem 279: 40545-40559. doi:10.1074/jbc .M402229200

Li D, Zhang J, Wang M, Li X, Gong H, Tang H, Chen L, Wan L, Liu Q. 2018. Activity dependent LoNA regulates translation by coordinating rRNA transcription and methylation. Nat Commun 9: 1726. doi:10.1038/ s41467-018-04072-4

Li X, Zhao Q, Wei W, Lin Q, Magnan C, Emami MR, Wearick-Silva LE, Viola TW, Marshall PR, Yin J, et al. 2019. The DNA modification $N^{6}$-methyl-2'-deoxyadenosine $\left(\mathrm{m}^{6} \mathrm{dA}\right)$ drives activity-induced gene expression and is required for fear extinction. Nat Neurosci 22: 534-544. doi:10.1038/s41593-019-0339-x

Lin Y, Bloodgood BL, Hauser JL, Lapan AD, Koon AC, Kim TK, Hu LS, Malik AN, Greenberg ME. 2008. Activity-dependent regulation of inhibitory synapse development by Npas4. Nature 455: 1198-1204. doi:10.1038/nature07319

Maity S, Jarome TJ, Blair J, Lubin FD, Nguyen PV. 2016. Noradrenaline goes nuclear: epigenetic modifications during long-lasting synaptic potentiation triggered by activation of $\beta$-adrenergic receptors. J Physiol 594: $863-881$. doi:10.1113/JP271432

Mao W, Salzberg AC, Uchigashima M, Hasegawa Y, Hock H, Watanabe M, Akbarian S, Kawasawa YI, Futai K. 2018. Activity-induced regulation of synaptic strength through the chromatin reader L3mbtl1. Cell Rep 23: 3209-3222. doi:10.1016/j.celrep.2018.05.028

Martin KC, Casadio A, Zhu H, Yaping E, Rose JC, Chen M, Bailey CH, Kandel ER. 1997. Synapse-specific, long-term facilitation of Aplysia sensory to motor synapses: a function for local protein synthesis in memory storage. Cell 91: 927-938. doi:10.1016/S0092-8674(00) 80484-5

Martínez G, Vidal RL, Mardones P, Serrano FG, Ardiles AO, Wirth C, Valdés P, Thielen P, Schneider BL, Kerr B. 2016. Regulation of memory formation by the transcription factor XBP1. Cell Rep 14: 1382-1394. doi:10.1016/j.celrep.2016.01.028

McNulty SE, Barrett RM, Vogel-Ciernia A, Malvaez M, Hernandez N, Davatolhagh MF, Matheos DP, Schiffman A, Wood MA. 2012 Differential roles for Nr4a1 and Nr4a2 in object location vs. object recognition long-term memory. Learn Mem 19: 588-592. doi:10.1101/ $\operatorname{lm} .026385 .112$

McQuown SC, Barrett RM, Matheos DP, Post RJ, Rogge GA, Alenghat T, Mullican SE, Jones S, Rusche JR, Lazar MA, et al. 2011. HDAC3 is a critical negative regulator of long-term memory formation. J Neurosci 31: 764 774. doi:10.1523/JNEUROSCI.5052-10.2011

Middleton SA, Eberwine J, Kim J. 2019. Comprehensive catalog of dendritically localized mRNA isoforms from sub-cellular sequencing of single mouse neurons. BMC Biol 17: 5. doi:10.1186/s12915-019-0630-z
Miller CA, Sweatt JD. 2007. Covalent modification of DNA regulates memory formation. Neuron 53: 857-869. doi:10.1016/j.neuron.2007.02 .022

Montarolo PG, Goelet P, Castellucci VF, Morgan J, Kandel ER, Schacher S. 1986. A critical period for macromolecular synthesis in long-term heterosynaptic facilitation in Aplysia. Science 234: 1249-1254. doi:10 $1126 /$ science. 3775383

Morris MJ, Mahgoub M, Na ES, Pranav H, Monteggia LM. 2013. Loss of histone deacetylase 2 improves working memory and accelerates extinction learning. J Neurosci 33: 6401-6411.

Nandi S, Chandramohan D, Fioriti L, Melnick AM, Hébert JM, Mason CE, Rajasethupathy P, Kandel ER. 2016. Roles for small noncoding RNAs in silencing of retrotransposons in the mammalian brain. Proc Natl Acad Sci 113: $12697-12702$. doi:10.1073/pnas.1609287113

Nudelman AS, DiRocco DP, Lambert TJ, Garelick MG, Le J, Nathanson NM, Storm DR. 2010. Neuronal activity rapidly induces transcription of the CREB-regulated microRNA-132, in vivo. Hippocampus 20: 492-498. doi:10.1002/hipo.20646

Oliveira AM, Hemstedt TJ, Bading H. 2012. Rescue of aging-associated decline in Dnmt3a2 expression restores cognitive abilities. Nat Neurosci 15: $1111-1113$. doi:10.1038/nn.3151

Penke Z, Morice E, Veyrac A, Gros A, Chagneau C, LeBlanc P, Samson N, Baumgärtel K, Mansuy IM, Davis S. 2014. Zif268/Egr1 gain of function facilitates hippocampal synaptic plasticity and long-term spatial recognition memory. Philos Trans R Soc B Biol Sci 369: 20130159. doi:10 $.1098 / \mathrm{rstb} .2013 .0159$

Rajasethupathy P, Antonov I, Sheridan R, Frey S, Sander C, Tuschl T, Kandel ER. 2012. A role for neuronal piRNAs in the epigenetic control of memory-related synaptic plasticity. Cell 149: 693-707. doi:10.1016/i .cell.2012.02.057

Ramamoorthi K, Fropf R, Belfort GM, Fitzmaurice HL, McKinney RM, Neve RL, Otto T, Lin Y. 2011. Npas4 regulates a transcriptional program in CA3 required for contextual memory formation. Science 334: 16691675. doi:10.1126/science. 1208049

Ramanan N, Shen Y, Sarsfield S, Lemberger T, Schütz G, Linden DJ, Ginty DD. 2005. SRF mediates activity-induced gene expression and synaptic plasticity but not neuronal viability. Nat Neurosci 8: 759-767. doi:10.1038/nn1462

Reverte CG, Ahearn MD, Hake LE. 2001. CPEB degradation during xenopus oocyte maturation requires a pest domain and the $26 s$ proteasome. Dev Biol 231: 447-458. doi:10.1006/dbio.2001.0153

Rudenko A, Dawlaty MM, Seo J, Cheng AW, Meng J, Le T, Faull KF, Jaenisch R, Tsai L-H. 2013. Tet1 is critical for neuronal activity-regulated gene expression and memory extinction. Neuron 79: 1109-1122. doi:10 $.1016 /$ j.neuron.2013.08.003

Sambandan S, Akbalik G, Kochen L, Rinne J, Kahlstatt J, Glock C, Tushev G, Alvarez-Castelao B, Heckel A, Schuman EM. 2017. Activity-dependent spatially localized miRNA maturation in neuronal dendrites. Science 355: 634-637. doi:10.1126/science.aaf8995

Schoberleitner I, Mutti A, Sah A, Wille A, Gimeno-Valiente F, Piatti P, Kharitonova M, Torres L, López-Rodas G, Liu JJ. 2019. Role for chromatin remodeling factor chd1 in learning and memory. Front Mol Neurosci 12: 3. doi:10.3389/fnmol.2019.00003

Schoch H, Abel T. 2014. Transcriptional co-repressors and memory storage Neuropharmacology 80: 53-60. doi:10.1016/j.neuropharm.2014.01.003

Scott HL, Tamagnini F, Narduzzo KE, Howarth JL, Lee YB, Wong LF, Brown MW, Warburton EC, Bashir ZI, Uney JB. 2012. MicroRNA-132 regulates recognition memory and synaptic plasticity in the perirhinal cortex. Eur J Neurosci 36: 2941-2948. doi:10.1111/j.1460-9568.2012 $.08220 . \mathrm{x}$

Si K, Giustetto M, Etkin A, Hsu R, Janisiewicz AM, Miniaci MC, Kim JH, $\mathrm{Zhu} \mathrm{H}$, Kandel ER. 2003a. A neuronal isoform of CPEB regulates local protein synthesis and stabilizes synapse-specific long-term facilitation in Aplysia. Cell 115: 893-904. doi:10.1016/S0092-8674(03)01021-3

Si K, Lindquist S, Kandel ER. 2003b. A neuronal isoform of the Aplysia CPEB has prion-like properties. Cell 115: 879-891. doi:10.1016/S0092-8674 (03)01020-1

Smolen P, Baxter DA, Byrne JH. 2019. How can memories last for days, years, or a lifetime? Proposed mechanisms for maintaining synaptic potentiation and memory. Learn Mem 26: 133-150. doi:10.1101/lm .049395 .119

Snigdha S, Prieto GA, Petrosyan A, Loertscher BM, Dieskau AP, Overman LE, Cotman CW. 2016. H3K9me3 inhibition improves memory, promotes spine formation, and increases BDNF levels in the aged hippocampus. $J$ Neurosci 36: 3611-3622. doi:10.1523/JNEUROSCI.2693-15.2016

Sossin WS, Costa-Mattioli M. 2018. Translational control in the brain in health and disease. Cold Spring Harb Perspect Biol doi:10.1101/ cshperspect.a032912

Szulwach KE, Li X, Li Y, Song CX, Wu H, Dai Q, Irier H, Upadhyay AK, Gearing M, Levey AI, et al. 2011. 5-hmC-mediated epigenetic dynamics during postnatal neurodevelopment and aging. Nat Neurosci 14: 16071616. doi:10.1038/nn.2959 
Tahiliani M, Koh KP, Shen Y, Pastor WA, Bandukwala H, Brudno Y, Agarwal S, Iyer LM, Liu DR, Aravind L, et al. 2009. Conversion of 5-methylcytosine to 5-hydroxymethylcytosine in mammalian DNA by mll partner tet1. Science 324: 930-935. doi:10.1126/science.1170116

Tang GB, Zeng YQ, Liu PP, Mi TW, Zhang SF, Dai SK, Tang QY, Yang L, Xu YJ, Yan HL, et al. 2017. The histone H3K27 demethylase UTX regulates synaptic plasticity and cognitive behaviors in mice. Front Mol Neurosci 10: 267 . doi: $10.3389 /$ fnmol.2017.00267

Uchida S, Teubner BJ, Hevi C, Hara K, Kobayashi A, Dave RM, Shintaku T, Jaikhan P, Yamagata H, Suzuki T. 2017. CRTC1 nuclear translocation following learning modulates memory strength via exchange of chromatin remodeling complexes on the Fgf1 gene. Cell Rep 18: 352366. doi:10.1016/j.celrep.2016.12.052

Upadhya SC, Smith TK, Hegde AN. 2004. Ubiquitin-proteasome-mediated CREB repressor degradation during induction of long-term facilitation. J Neurochem 91: 210-219. doi:10.1111/j.1471-4159.2004.02707.x

Van Driesche SJ, Martin KC. 2018. New frontiers in RNA transport and local translation in neurons. Dev Neurobiol 78: 331-339. doi:10.1002/dneu .22574

Vo N, Klein ME, Varlamova O, Keller DM, Yamamoto T, Goodman RH, Impey S. 2005. A cAMP-response element binding protein-induced microRNA regulates neuronal morphogenesis. Proc Natl Acad Sci 102: 16426-16431. doi:10.1073/pnas.0508448102

Yamakawa H, Cheng J, Penney J, Gao F, Rueda R, Wang J, Yamakawa S, Kritskiy O, Gjoneska E, Tsai L-H. 2017. The transcription factor Sp3 cooperates with HDAC2 to regulate synaptic function and plasticity in neurons. Cell Rep 20: 1319-1334. doi:10.1016/j.celrep.2017.07.044
Yin JC, Tully T. 1996. CREB and the formation of long-term memory. Curr Opin Neurobiol 6: 264-268. doi:10.1016/S0959-4388(96)80082-1

Yin JC, Wallach JS, Del Vecchio M, Wilder EL, Zhou H, Quinn WG, Tully T. 1994. Induction of a dominant negative CREB transgene specifically blocks long-term memory in Drosophila. Cell 79: 49-58. doi:10.1016/ 0092-8674(94)90399-9

Youn HD, Liu JO. 2000. Cabin1 represses MEF2-dependent Nur77 expression and $\mathrm{T}$ cell apoptosis by controlling association of histone deacetylases and acetylases with MEF2. Immunity 13: 85-94. doi:10 .1016/S1074-7613(00)00010-8

Zhang J, Ji F, Liu Y, Lei X, Li H, Ji G, Yuan Z, Jiao J. 2014. Ezh2 regulates adult hippocampal neurogenesis and memory. J Neurosci 34: 5184-5199. doi:10.1523/JNEUROSCI.4129-13.2014

Zhou L, Zhang Y, Liu RY, Smolen P, Cleary LJ, Byrne JH. 2015. Rescue of impaired long-term facilitation at sensorimotor synapses of Aplysia following siRNA knockdown of CREB1. J Neurosci 35: 1617-1626. doi:10 .1523/JNEUROSCI.3330-14.2015

Zhu Y, Huang M, Bushong E, Uytiepo M, Beutter E, Boemer D, Ellisman M, Maximov A. 2019. Class IIa HDACs regulate learning and memory through dynamic experience-dependent repression of transcription. bioRxiv: 540856. doi:10.1101/540856

Received April 23, 2019; accepted in revised form June 20, 2019. 


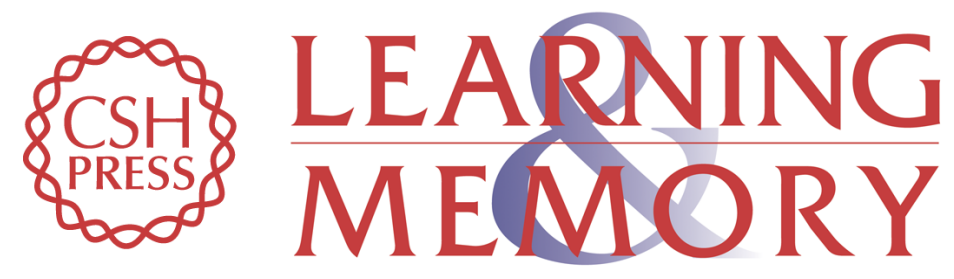

\section{Recent developments in transcriptional and translational regulation underlying long-term synaptic plasticity and memory}

Ashok N. Hegde and Spencer G. Smith

Learn. Mem. 2019, 26:

Access the most recent version at doi:10.1101/Im.048769.118

\begin{aligned} & \hline References $\begin{array}{l}\text { This article cites } 104 \text { articles, } 36 \text { of which can be accessed free at: } \\ \text { http://learnmem.cshlp.org/content/26/9/307.full.html\#ref-list-1 }\end{array} \\ & \begin{array}{r}\text { Creative } \\ \text { Commons } \\ \text { License }\end{array} \begin{array}{l}\text { This article is distributed exclusively by Cold Spring Harbor Laboratory Press for the } \\ \text { first } 12 \text { months after the full-issue publication date (see } \\ \text { http://learnmem.cshlp.org/site/misc/terms.xhtml). After } 12 \text { months, it is available under } \\ \text { a Creative Commons License (Attribution-NonCommercial } 4.0 \text { International), as } \\ \text { described at http://creativecommons.org/licenses/by-nc/4.0/. }\end{array} \\ & \begin{array}{c}\text { Receive free email alerts when new articles cite this article - sign up in the box at the } \\ \text { top right corner of the article or click here. }\end{array} \\ &$ Service \end{aligned} 